\title{
DynamicSainT
}

\author{
Jilid. V No. 1., April 2020
}

\section{MORTAR GEOPOLIMER ABU SEKAM PADI BERBAHAN DASAR LIMBAH ABU BATU BARA HASIL PEMBAKARAN ASPHALT MIXING PLANT}

\author{
Parea Rusan Rangan ${ }^{*}$, Ermitha A.R. Dendo ${ }^{2}$, Jacob Bokko ${ }^{3}$, Pramana Angga Mantirri ${ }^{4}$ \\ Program Studi Teknik Sipil, Fakultas Teknik, Universitas Kristen Indonesia Toraja. \\ Jl. Nusantara No. 12,Makale, Tana Toraja, Sulawesi Selatan \\ 1*pareausanrangan68@gmail.com, ${ }^{2}$ ambun.rombe@gmail.com, ${ }^{3}$ jacobbokkosipil@gmail.com
}

\begin{abstract}
ABSTRAK
Mortar atau spesi adalah campuran semen, pasir dan air serta bahan perekat, dan diaduk sampai homogen. Mortar merupakan bahan bangunan berbahan dasar semen yang digunakan sebagai "perekat" untuk membuat struktur bangunan. Penelitian ini dilakukan bertujuan untuk menemukan material alternatif pengganti semen. Abu terbang produk sisa pembakaran batubara sebagai bahan pengganti semen merupakan bahan pozzolanic yaitu sifat pengikat seperti semen dari abu terbang dan sekam padi dapat meningkatkan kuat tekan mortar geopolymer. Aktivator yang digunakan adalah Sodium Hidroksida (NaOH) yang berfungsi mempercepat proses polimerisasi antar partikel. Abu sekam padi merupakan hasil pembakaran dari olahan padi yang mengandung silika yaitu senyawa kimia dengan rumus molekul $\mathrm{SiO}^{2}$ yang memberikan kontribusi dalam proses pengerasan maupun peningkatan kuat tekan pada mortar. Penelitian ini menggunakan benda uji berbentuk kubus 5x5x5 cm, uji tekan dilakukan pada umur 3,7,14 dan 28 hari setelah melalui proses perawatan masing-masing tiga buah sampel. Dengan mennggunakan 15 molaritas, Hasil kuat tekan terbaik mortar ialah pada usia 28 hari dengan kuat tekan 3,13 MPa untuk perawatan suhu udara terbuka dan 3,49 MPa untuk curing perendaman dalam air, Semakin tinggi molaritas yang digunakan dalam komposisi campuran maka semakin cepat proses pengerasan mortar geopolimer. Semakin panjang umur benda uji maka semakin tinggi nilai kuat tekan. Metode Perawatan yang paling baik dilakukan untuk mortar geopolimer adalah perendaman di dalam air, Hasil pengujian kuat tekan proses perawatan perendaman memiliki kuat tekan yang lebih tinggi dibandingkan dengan metode perawatan suhu udara terbuka.
\end{abstract}

Kata Kunci : Mortar Geopolimer, Abu Terbang, Abu Sekam Padi, Curing, Kuat Tekan

\section{PENDAHULUAN}

Semen adalah bahan perekat berbentuk serbuk atau tepung yang terbuat dari kapur dan material lainnya yang dipakai untuk membuat beton, merekatkan batu bata ataupun membuat dinding tembok.

Berdasarkan Standar Nasional Indonesia (SNI) nomor 15-2049-2004 tentang semen Portland adalah semen hidrolisis yang dihasilkan dengan cara menggiling terak (clinker) portland terutama yang terdiri dari kalsium silikat (xCaO.SiO2) yang bersifat hidrolis dan digiling bersama-sama dengan bahan tambahan berupa satu atau lebih bentuk kristal senyawa kalsium sulfat (CaSO4.xH2O) dan boleh ditambah dengan bahan tambahan lain. Semen Portland adalah bahan yang digunakan dalam pembuatan mortar sebagai pelapis beton untuk pembangunan infrakstruktur, sehingga setiap tahun produksi semen setiap tahun semakin meningkat. Seiring dengan peningkatan industri pabrik semen dalam proses pembuatan semen akan menghasilkan karbondioksida ke udara yang dapat menyebabkan terjadinya pemanasan. Untuk mengatasi efek buruk yang merusak lingkungan dan memperbaiki masalah durabilitas pada material beton yang menggunakan Semen Portland, maka diperlukan material lainnya sebagai pengganti.

Geopolymer merupakan sintesa bahan- 


\section{DynamicSainT}

Jilid. V No. 1., April 2020

bahan alam non organik lewat proses polimerisasi dalam volume reaksi kimia oksida alumina-silikat dengan alkali polisilat menghasilkan ikatan Si-O-Al polimerik (Davidovits, 1991). Bahan dasar utama yang diperlukan untuk pembuatan material geopolimer ini adalah bahan-bahan yang banyak mengandung unsur-unsur silika dan alumina. Unsur-unsur ini banyak didapati pada material hasil sampingan industri, seperti fly ash dari sisa pembakaran batu bara dan sekam padi.

Material fly ash dalam pembuatan mortar dapat saja beraksi secara kimia dengan cairan alkalin pada temperatur tertentu untuk membentuk material campuran yang memiliki sifat seperti semen. Material geopolimer ini digabungkan dengan agregat batuan kemudian menghasilkan mortar geopolimer, tanpa menggunakan semen lagi (Rangan P. R., Irmawaty, Amiruddin, \& Bakri, 2020).

Sekam padi merupakan limbah yang berasal dari penggilingan padi yang banyak dijumpai di berbagai tempat, sekam ini biasanya hanya dikumpulkan pada suatu tempat pembuangan dan dibiarkan begitu saja hingga menumpuk. Abu dari hasil pembakaran sekam padi ini memiliki unsur silika yang relatif mirip dengan semen, penelitian ini bertujuan untuk memanfaatkan sekam padi sehingga sekam padi nantinya bisa menjadi produk baru sebagai bahan konstruksi bangunan. Berawal dari permasalahan tersebut maka dilakukan penelitian tentang pemanfaatan bahan buangan hasil produksi dengan harapan sebagai salah satu upaya gerakan ramah lingkungan dan menjadikan inovasi dalam industri penggunaan beton yang berupa pasta geopolimer dengan bahan utamanya menggunakan fly-ash yang dikombinasikan dengan abu sekam padi. Hasil penelitian menunjukkan geopolimer satu bagian diproduksi dari abu sekam padi (RHA) dengan mencampurkan RHA dengan natrium aluminat padat pada rasio untuk menghasilkan $\mathrm{SiO} 2 / \mathrm{Al} 2 \mathrm{O} 3=3,5$ dan selanjutnya mencampur campuran padat dengan air dan proses curing pada suhu $80^{\circ}$ $\mathrm{C}$ dan $80 \%$ r.H. Kekuatan tekan geopolimer adalah $30 \mathrm{MPa}$ setelah satu hari pengeringan (Sturm, G.JG, Brouwers, \& Kuhne, 2016).

Abu sekam padi dan abu batubara, kedua bahan tersebut lolos saringan 200 dan 100 hingga sesuai dengan ukuran butir pozzolan yang akan membuat proses pengikatan lebih mudah. Penelitian ini bertujuan untuk mendapatkan sumber baru pozzolan yang tidak hanya berasal dari semen saja, namun bisa berasal dari alam yang berupa zat buangan untuk alternatif penggunaan semen. Permasalahan yang akan dibahas adalah seberapa besar komposisi campuran abu sekam padi dan abu batubara serta alkali aktivator pada mortar geopolimer serta bagaimana kuat tekan yang dihasilkan oleh mortar geopolimer. Geopolimer yang diaktifkan dengan natrium hidroksida $(\mathrm{NaOH}) 12$ Molar dengan perlakuan

curing udara setelah 28 hari menunjukkan hasil bahwa peningkatan waktu curing meningkatkan kekuatan tekan (Rangan P. R., Irmawaty, Amiruddin, \& Bakri, 2020).

\section{LITERATURE STUDY}

\subsection{Mortar Geopolimer}

Mortar geopolimer adalah campuran antara pasir, semen dan air yang mana semen tersebut digantikan oleh senyawa yang kandungannya menyerupai semen atau bahan pengikatnya tidak menggunakan semen $100 \%$, sedangkan pasta geopolimer adalah campuran antara air dan semen yang mana semen tersebut digantikan oleh senyawa yang kandungannya menyerupai semen atau bahan penyusunnya $100 \%$ tidak menggunakan semen, tetapi menggunakan bahan alami yang banyak mengandung unsur Silika $(\mathrm{Si})$ dan unsur Alumina (Al). Bahan tersebut dapat ditemukan pada hasil sampingan Pembangkit 


\section{DynamicSainT}

Jilid. V No. 1., April 2020

Listrik Tenaga Uap dan pabrik-pabrik tertentu antara lain Asphalt Mixing Plant (AMP).

Pasta semen bila semen dicampur dengan air, butir semen akan tersebar didalam air. Suspensi ini berubah dari keadaan cair menjadi plastis atau kaku dengan ditambahkan semen. Ruang yang penuh air diantara butiran semen dapat dianggap sebagai sistem kapiler yang saling berhubungan.

Jumlah air tidak hanya mempengaruhi kelecakan, tetapi juga hampir semua sifat beton segar maupun beton keras. Semakin sedikit air, semakin tinggi konsetrasi butir semen dalam pasta semen padat. Salah satu sifat pasta semen adalah faktor air-semen (sering ditulis w/c, water/cement ratio) adalah berat air dibagi dengan berat semen. Kepadatan relatif pasta semen segar bisa juga dihitung dari komposisinya seperti faktor airsemen $0,3,0,5$ dan 0,8 maka kepadatan ratarata yang dihasilkan $2,1,1,8$, dan $1,6 \mathrm{gr} / \mathrm{cm} 3$. Sifat beton segar tergantung sifat dan jumlah matriks dan agregat seperti pengurangan matriks akan mengurangi derajat penyebaran butir agregat, sehingga menambah gesekan antarbutir, yang akan selanjutnya akan memperkaku beton segar. Semakin tinggi faktor air-semen cenderung mengalami segresi dan pendarahan (bleeding), dan tidak mempunyai plastisitas dan kelecakan yang cukup (Nugraha dan Antoni, 2007).

\subsection{Kuat Tekan}

Kuat tekan adalah kemampuan mortar untuk menahan gaya luar yang datang pada arah sejajar serat yang menekan mortar. Mortar yang digunakan untuk bahan bangunan harus mempunyai kekuatan terutama untuk pasangan dinding batu bata, pasangan dinding batako atau pansangan dinding yang lainnya.(Tjokrodimulio 1992) sebagai berikut:

$$
\mathrm{f}^{\prime} \mathrm{c}=\frac{\mathrm{F}}{\mathrm{A}}
$$

keterangan:

$\mathrm{f}^{\prime} \mathrm{c}=$ Kuat Tekan $(\mathrm{MPa})$
$\mathrm{F}=$ Beban Tekan $(\mathrm{N})$

$\mathrm{A}=$ Luas Penampang $\left(\mathrm{mm}^{2}\right)$

\subsection{Abu Terbang (Fly ash)}

Abu terbang (Fly ash) merupakan sisa dari hasil pembakaran batubara pada power plants. Fly ash mempunyai titik lebur sekitar $1300^{\circ} \mathrm{C}$ dan berdasarkan uji komposisi kimia fly ash mengandung CAS (CO-Al2O3-SiO2) dalam jumlah besar yang merupakan pembentuk utama network glass. Fly ash mempunyai kerapatan massa (densitas), antara 2,0 - 2,5 g/cm3 (Bienias, Walczak, Surowska, \& Sobczak, 2003).

Dalam dunia industri, abu terbang biasanya mengacu pada abu yang dihasilkan selama pembakaran batu bara. Abu terbang umumnya ditangkap oleh pengendap elektrostatik atau peralatan filtrasi partikel lain sebelum gas buang mencapai cerobong asap batu bara pembangkit listrik, dan bersama-sama dengan bottom ash dikeluarkan dari bagian bawah tungku dalam hal ini bersama-sama dikenal sebagai abu batu bara. Tergantung pada sumber dan tampilan batu bara yang dibakar, komponen abu terbang bervariasi, tetapi semua abu terbang termasuk sejumlah besar silikon dioksida (SiO2) (baik amorf dan kristal) dan kalsium oksida $(\mathrm{CaO})$, kedua bahan endemik yang di banyak terdapat dalam lapisan batuan batu bara. Secara kimia fly ash merupakan mineral alumino silikat yang banyak mengandung unsur-unsur $\mathrm{Ca}, \mathrm{K}$, dan $\mathrm{Na}$ disamping juga mengandung sejumlah kecil unsur $\mathrm{C}$ dan $\mathrm{N}$. Bahan nutrisi dalam fly ash yang diperlukan dalam tanah diantaranya adalah $\mathrm{B}, \mathrm{P}$ dan unsur-unsur lainnnya seperti $\mathrm{Cu}, \mathrm{Zn}, \mathrm{Mn}$, Mo dan Se. Fly ash sendiri dapat bersifat sangat asam ( $\mathrm{pH} 3-4)$ tetapi pada umumnya bersifat basa ( $\mathrm{pH} 10$ - 12). Secara fisika fly ash batubara tersusun dari partikel berukuran silt yang mempunyai karakteristik kapasitas pengikat air dari sedang sampai tinggi. (Retno, 2006)

Fly ash merupakan salah satu limbah padat yang dihasilkan oleh industri yang 


\section{DynamicSainT}

Jilid. V No. 1., April 2020

menggunakan batubara sebagai bahan bakar untuk proses produksinya. Fly ash memiliki sifat sebagai pozzolan, yaitu suatu bahan yang mengandung silika atau alumina yang tidak mempunyai sifat perekat (sementasi) pada dirinya sendiri tetapi dengan butirannya yang sangat halus bisa bereaksi secara kimia dengan aktivator dan air membentuk bahan perekat pada temperatur normal.

Saat ini jumlah limbah batubara (fly ash) di dunia yang dihasilkan dari proses pembakaran batubara di PLTU sangatlah besar, termasuk di Indonesia. Sejalan dengan hal tersebut, sejumlah industri seperti TPT, petrokimia, semen, dan pupuk, dan berbagai manufaktur lainnya juga mulai mengganti sumber energinya ke batubara. Termasuk juga PT PLN (Persero) banyak membangun PLTU yang energi primernya adalah batubara. Dengan tingginya penggunaan batubara, maka fly ash dan bottom ash (faba) yang tidak termanfaatkan, akan menggunung sehingga menghasilkan limbah ampas batubara. Di sisi lain banyak pembangunan infrastruktur yang dapat memanfaatkan Faba sebagai bahan dasar atau campuran, untuk pembangunan jalan dan sebagainya. Limbah batubara yang relatif besar ini menimbulkan dampak pencemaran yang cukup berat. Sehingga perlu dipikirkan sebuah alternatif pemecahan permasalahan limbah ini.

Bahan yang digunakan untuk abu batu bara diambil dari limbah hasil pembakaran batu bara saat proses pembuatan campuran aspal panas di asphalt mixing plant (AMP). Batu bara digunakan sebagai bahan bakar di AMP saat pembuatan campuran aspal panas, batu bara merupakan sebagai bahan pengganti bahan bakar minyak yaitu minyak diesel (solar). Lokasi AMP di Kecamatan Rantetayo, Makale, Kabupaten Tana Toraja, milik PT. Sabar Jaya Pratama

Ada beberapa jenis fly ash menurut SNI S-15-1990-F tentang spesifikasi abu terbang sebagai bahan tambahan untuk campuran beton, abu batubara (fly ash) digolongkan menjadi 3 jenis, yaitu :

\section{Fly Ash Kelas N}

Buangan atau pozzolan alam terkalsinasi yang dipenuhi dengan kebutuhan yang memenuhi syarat yang dapat dipakai sesuai kelasnya, seperti beberapa tanah diatomaceous, opalinse chert dan serpihan-serpihan tuff dan debu-debu vulkanik atau pumicities, dan bahan-bahan lainnya yang mungkin masih belum terproses oleh kalsinasi; dan berbagai material yang memerlukan kalsinasi untuk memperoleh sifat-sifat yang memuaskan, misalnya beberapa jenis tanah liat dan serpihan-serpihan.

\section{Fly Ash Kelas F}

Abu batubara yang umumnya diproduksi dari pembakaran anthracite (batubara keras yang mengkilat) atau bitumen-bitumen batubara yang memenuhi syarat-syarat yang dapat dipakai untuk kelas ini seperti yang disyaratkan. Abu batubara jenis ini memiliki sifat Pozzolanic.

\section{Fly Ash Kelas C}

Abu batubara yang umumnya diproduksi dari lignite atau batubara subitumen yang memenuhi syarat yang dapat dipakai untuk kelas ini seperti yang disyaratkan. Abu batubara kelas ini, selain memiliki sifat pozzolan juga memiliki beberapa sifat yang lebih menyerupai semen. Untuk beberapa abu batubara kelas $\mathrm{C}$ bias mengandung kapur lebih tinggi dari 10 Adapun susunan kimia dan sifat fisik abu batubara menurut ASTM C618 - 91 (Husin, 1998), ditunjukkan pada Tabel 1.

Tabel 1. Unsur senyawa kimia dan sifat fisika pada fly ash

\begin{tabular}{|l|l|l|}
\hline $\begin{array}{l}\text { Susunan kimia dan } \\
\text { fisika }\end{array}$ & $\begin{array}{l}\text { Kelas } \\
(\mathbf{\%})\end{array}$ & $\begin{array}{l}\text { Kelas C } \\
(\mathbf{\%})\end{array}$ \\
\hline Silikon dioksida, min & 54,90 & 39,90 \\
\hline Sulfur trioksida, max & 5,0 & 5,0 \\
\hline Kadar air, max & 3,0 & 3,0 \\
\hline Hilang pijar, max & 6,0 & 6,0 \\
\hline Na2O, max & 1,5 & 1,5 \\
\hline
\end{tabular}

Sumber : Andriati Amir Husin

\subsection{Natrium Hidroksida ( $\mathrm{NaOH})$}

Natrium Hidroksida adalah senyawa 


\section{DynamicSainT}

Jilid. V No. 1., April 2020

kimia dengan kandungan alkali tinggi. Sifatsifat kimia membuatnya ideal untuk digunakan dalam berbagai aplikasi yang berbeda, termasuk pembuatan produk pembersih, pemurnian air dan pembuatan produk kertas. Karena kandungan alkali, natrium hidroksida menyebabkan iritasi kulit yang kuat, sehingga perlu untuk menangani produk dengan hati-hati selama penggunaannya.

Dalam bentuk murni, natrium hidroksida berbentuk serpih atau pelet yang putih cerah. Dalam bentuk ini, secara kimia mudah menyerap karbon dioksida dari udara di ruang, ini membuat perlu tempat khusus bagi produk ini dalam penyimpanannya, sehingga perlu disimpan dalam wadah yang kedap udara. Fakta bahwa natrium hidroksida yang larut dalam air membantu untuk membuatnya ideal untuk digunakan dalam sejumlah produk berbasis larutan.

Senyawa alkali ini dapat dimanfaatkan dalam berbagai jenis produk yang digunakan di rumah serta di bidang manufaktur dan industri lainnya. Di sekitar rumah,natrium hidroksida digunakan untuk membuat yang sabun digunakan untuk mandi, mesin pencuci piring dan pencuci pakaian mengandung beberapa jumlah natrium hidroksida. pembersih rumah tangga untuk karpet dan ubin juga mungkin memiliki beberapa sejumlah kecil senyawa juga. Jumlah tersebut sebenarnya digunakan dalam jenis produk sangat sedikit, sehingga sangat tidak mungkin bahwa kontak dengan kulit akan menyebabkan iritasi.

Dalam geopolymer peranan Natrium Hidroksida adalah sebagai pengaktif unsur yang yang terkandung dalam abu sekam dan fly ash sehingga terbentuk ikatan polimer.

Rumus menentukan konsentrasi molaritas untuk menghitung 1 liter larutan $\mathrm{NaOH} 12 \mathrm{M}$ adalah sebagai berikut : $\mathrm{n}=\mathrm{V} \times \mathrm{M}$

Dimana : $\mathrm{n} \quad=$ jumlah mol zat tersebut

$\mathrm{M}=$ kemolaran larutan

$\mathrm{V}=$ volume larutan

$$
\text { Massa } \begin{aligned}
\mathrm{NaOH} & =\mathrm{n} \text { mol } \times \mathrm{Mr} \\
& =12 \mathrm{~mol} \times 40 \mathrm{gram} / \mathrm{mol} \\
& =480 \text { gram }
\end{aligned}
$$

\subsection{Air}

Air merupakan komponen penting dari campuran pasta dan mortar yang memegang salah satu faktor penting, karena air dapat bereaksi dengan semen, yang akan menjadi pasta pengikat agregat. Kualitas air mempengaruhi kekuatan pasta dan mortar, maka kemurnian dan kualitas air untuk campuran pasta dan mortar perlu mendapat perhatian. Air untuk pembuatan dan perawatan pasta dan mortar tidak boleh mengandung minyak, asam alkali,garam, bahan-bahan organic, atau bahan lain yang dapat merusak pasta dan mortar. Sebaiknya digunakan air bersih, air tawar, tidak berbau, bila dihembuskan dengan udara tidak keruh, tidak berasa, dan dapat diminum. Air sebagai bahan bangunan sebaiknya memenuhi syarat Standar SK SNI S-04-1989-F, Spesifikasi Bahan Bangunan Bagian A)

1. Air harus bersih.

2. Tidak mengandung lumpur, minyak, dan benda melayang lainnya yang dapat dilihat secara visual dan tidak boleh lebih dari 2 gram per liter.

3. Tidak mengandung garam-garam yang dapat larut dan dapat merusak (asam, zat organik, dan sebagainya) lebih dari 15 gram per liter.

4. Tidak mengandung klorida $(\mathrm{Cl})$ lebih dari 0,5 gram per liter..

5. Tidak mengandung senyawa sulfat (sebagai SO3) lebih dari 1 gram per liter.

Kualitas mortar akan berkurang bila air mengandung kotoran. Pengaruh pada mortar diantaranya pada lamanya waktu ikatan awal adukan mortar, kekuatannya, serta kekedapan airnya setelah mortar mengeras. adanya butiran melayang (lumpur) dalam air di atas 2 gram/liter dapat mengurangi kekuatan mortar 


\section{DynamicSainT}

Jilid. V No. 1., April 2020

diantaranya pada lamanya waktu ikatan awal adukan mortar, kekuatannya, serta kekedapan airnya setelah mortar mengeras.

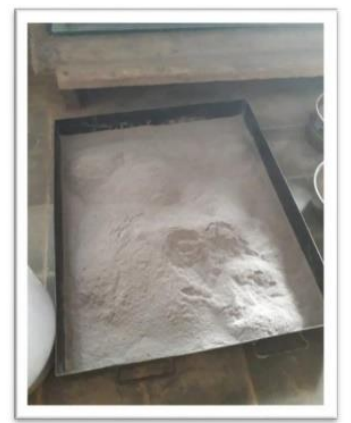

Abu Sekam Padi

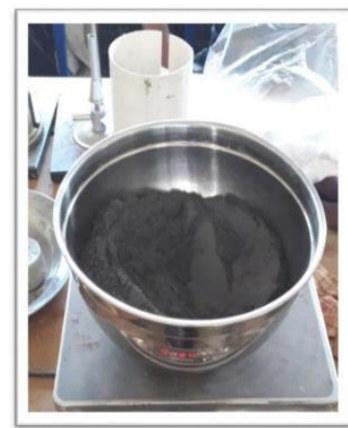

Abu Batubara
Gambar 1. Abu Sekam \& Abu Batubara

\section{METODOLOGI}

Metodologi yang di terapkan pada penelitian ini adalah studi experimental, yakni melakukan percobaan trial and error dengan acuan penelitian sebelumya di labolatorium. Penelitian ini dimaksudkan untuk mengetahui komposisi abu sekam padi, fly ash dan aktifator terhadap semen geopolimer yang akan di uji kuat tekannya.

Pelaksanaan penelitian diawali dengan studi pustaka, dilanjutkan dengan penelitian di Laboratorium Teknik Sipil Fakultas Teknik Universitas Kristen Indonesia Toraja.

Adapun tahapan pelaksanaan penelitian sebagai berikut:

- Persiapan alat dan bahan penelitian.

- Penyaringan abu terbang batu bara yang lolos saringan no 200.

- abu sekam yang lolos saringan no 100 .

- Perencanaan komposisi campuran.

- Pembuatan benda uji.

a) Pembuatan campuran beton (Mixing).

b) Pencetakan (Moulding).

c) Perawatan (Curing) ruangan dan air

- Pengujian kuat tekan untuk setiap benda uji.

- Menganalisa data hasil pengujian yang telah dilakukan.

Abu batu bara diambil dari sisa pembakaran dari produksi campuran aspal panas. Batu bara di sini digunakan sebagai bahan bakar untuk memanasi campuran aspal di AMP.
Metode pengujian dan peralatan yang digunakan dalam pengujian sesuai SNI atau sesuai persyaratan lainnya dalam metode uji.
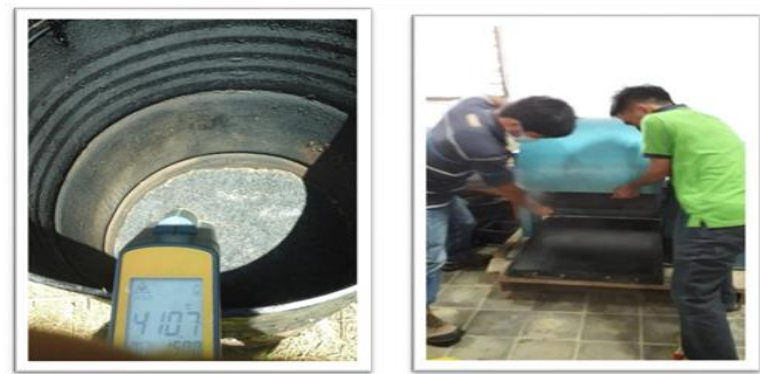

Gambar 2. Proses Pembakaran \& penghalusan Abu sekam Padi

Mix design pada penelitian ini dilakukan untuk mengetahui pengaruh konsentrasi $\mathrm{NaOH}$ terhadap kekuatan tekan beton pada umur 7, 14, 21, dan 28 hari. Konsentrasi $\mathrm{NaOH}$ yang digunakan yaitu 12 Molar. Sekam padi yang dijadikan bahan penelitian adalah limbah pembuangan dari pabrik penggilingan padi yang ada di desa Tallunglipu Induk, Kecamatan Tallunglipu, Kabupaten Tana Toraja. Sekam padi tersebut lalu di jemur hingga kering kemudian dibakar dalam wadah sampai mencapai suhu sekitar $400^{\circ} \mathrm{C}$.

\section{ANALISIS DAN PEMBAHASAN}

\subsection{Komposisi Campuran (Mix Design)}

Adapun beberapa percobaan rancangan camporan yang telah dibuat dalam penelitian ini dengan metode coba-coba adalah seperti berikut :

Tabel 2. Percobaan penentuan komposisi campuran mortar

\begin{tabular}{|c|c|c|c|c|c|c|c|}
\hline \multirow{2}{*}{$\begin{array}{l}\mathrm{N} \\
\mathrm{O}\end{array}$} & \multicolumn{2}{|c|}{$\begin{array}{l}\text { Persentase } \\
\text { Campuran }\end{array}$} & \multirow{2}{*}{$\begin{array}{c}\text { Abu } \\
\text { Ter } \\
\text { ban } \\
\text { g } \\
\text { (gra } \\
\text { m) }\end{array}$} & \multirow{2}{*}{$\begin{array}{c}\text { Abu } \\
\text { Sekam } \\
\text { Padi } \\
\text { (gram) }\end{array}$} & \multirow{2}{*}{$\begin{array}{l}\mathrm{NaOH} \\
\text { (gram) }\end{array}$} & \multirow{2}{*}{$\begin{array}{c}\text { Air } \\
(\mathrm{ml})\end{array}$} & \multirow[b]{2}{*}{$\begin{array}{l}\text { mo } \\
\text { lar }\end{array}$} \\
\hline & $\begin{array}{l}\text { Abu } \\
\text { terb } \\
\text { ang }\end{array}$ & $\begin{array}{c}\text { Abu } \\
\text { seka } \\
\text { m }\end{array}$ & & & & & \\
\hline 1 & \multirow{5}{*}{$\begin{array}{l}\mathbf{5 0} \\
\%\end{array}$} & \multirow{5}{*}{$\begin{array}{l}50 \\
\%\end{array}$} & 300 & 300 & 84 & 175 & 12 \\
\hline 2 & & & 300 & 300 & 240 & 500 & 12 \\
\hline 3 & & & 250 & 250 & 168 & 350 & 12 \\
\hline 4 & & & 250 & 250 & 132 & 275 & 12 \\
\hline 5 & & & 250 & 250 & 165 & 275 & 15 \\
\hline
\end{tabular}




\section{DynamicSainT}

Jilid. V No. 1., April 2020

\begin{tabular}{|c|c|c|c|c|c|c|c|}
\hline 6 & \multirow{4}{*}{$\begin{array}{l}75 \\
\%\end{array}$} & \multirow{4}{*}{$\begin{array}{l}15 \\
\%\end{array}$} & 375 & 125 & 84 & 175 & 12 \\
\hline 7 & & & 375 & 125 & 168 & 350 & 12 \\
\hline 8 & & & 375 & 125 & 132 & 275 & 12 \\
\hline 9 & & & 375 & 125 & 165 & 275 & 15 \\
\hline 10 & \multirow{2}{*}{$\begin{array}{l}85 \\
\%\end{array}$} & \multirow{2}{*}{$\begin{array}{l}15 \\
\%\end{array}$} & 425 & 75 & 132 & 275 & 12 \\
\hline 11 & & & 425 & 75 & 165 & 275 & 15 \\
\hline
\end{tabular}

mempunyai hasil yang homogen dan cetakan bisa dibuka setelah 24. Benda uji yang dihasikan dari campuran mortar ini komposisi tidak mengalami keretakan selama masa perawatan. Komposisi inilah yang akan digunakan untuk benda membuat benda uji 3,7, 14 dan 28 hari.

- No 1-5, Abu Terbang 50\% dan abu sekam padi $50 \%$ untuk 12 dan 15 Molar campuran mortar geopolimer mempunyai hasil yang tidak homogen antara abu sekam padi, abu terbang dan alkali aktifator sehingga campuran tidak dapat dicetak.

- No 6, 500gram material: abu terbang $75 \%$ dan abu sekam padi $25 \%$ dengan aktifator 175 ml untuk 12 Molar, campuran mortar mempunyai hasil yang tidak homogen karena kadar air yang terlalu sedikit sehingga campuran tidak dapat dicetak.

- No 7, 500gram material: abu terbang 75\% dan abu sekam padi $25 \%$ dengan aktifator $350 \mathrm{ml}$ untuk 12 Molar, campuran mortar mempunyai hasil terlalu encer karena kadar air yang terlalu banyak.

- No 8, 500gram material: abu terbang 75\% dan abu sekam padi $25 \%$ dengan aktifator $275 \mathrm{ml}$ untuk 12 Molar, campuran mortar mempunyai hasil yang homogen dan bisa dilakukan pencetakan benda uji, cetakan bisa dibuka pada umur 2 hari. Benda uji mengalami retak sebagian bila cetakan dibuka.

- No 9, 500gram material: abu terbang 75\% dan abu sekam padi $25 \%$ dengan aktifator 275 ml untuk 15 Molar, campuran mortar mempunyai hasil yang homogen dan bisa dilakukan pencetakan benda uji, cetakan bisa dibuka setelah 24 jam. Benda uji yang dihasikan dari campuran mortar ini akan mengalami retak pada usia lebih dari 10 hari masa perawatan.

- No 10, 500gram material: abu terbang $85 \%$ dan abu sekam padi $15 \%$ dengan aktifator $275 \mathrm{ml}$ untuk 12 Molar, campuran mortar mempunyai hasil yang homogen dan bisa dilakukan pencetakan benda uji, cetakan bisa dibuka setelah 24 jam. Benda uji yang dihasikan dari campuran mortar ini akan mengalami retak pada usia lebih dari 7 hari masa perawatan

- No 11, 500gram material: abu terbang $85 \%$ dan abu sekam padi $15 \%$ dengan aktifator $275 \mathrm{ml}$ untuk 15 Molar, campuran mortar

Tabel 3. komposisi terbaik campuran mortar

\begin{tabular}{|c|c|}
\multicolumn{2}{c}{ geopolimer } \\
\hline Material & Jumlah material \\
\hline Fly ash & 425 gram \\
\hline Abu sekam & 75 gram \\
\hline $\mathrm{NaOH}$ & 165 gram \\
\hline Air & $275 \mathrm{ml}$ \\
\hline Moralitas & $\mathbf{1 5}$ \\
\hline
\end{tabular}

Berdasarkan hasil dari beberapa percobaan yang telah dilakukan maka diperoleh komposisi campuran yang paling optimal yaitu 500 gram, jumlah material yang ditentukan berdasarkan jumlah benda uji yang dapat dihasilkan dari 1 buah cetakan, campuran ini dapat menghasilkan 3 buah benda uji berbentuk kubus dengan ukuran $50 \times 50 \times 50 \mathrm{~mm}$. Material yang terdiri dari $85 \%$ fly ash dan $15 \%$ abu sekam dengan jumlah cairan aktifator yang disesuaikan.

\subsection{Metode perawatan (curing)}

Dari beberapa metode yang telah dilakukan dalam perawatan didapatkan hasil kuat tekan mortar yang berbeda pula di tiap perlakuan.

- Metode perawatan perendaman dalam air berhasil selama usia 3 hari. Selanjutnya dilakukan perawatan pada usia 7,14, 28 hari.

- Metode perawatan dengan suhu udara terbuka berhasil selama usia 3 hari. Selanjutnya dilakukan perawatan pada usia 7,14,dan 28 hari.

- Metode perawatan oven gagal karena benda uji mengalami keretakan.

- Metode perawatan yang paling baik dipergunakan ialah dengan perendaman dalam air karena kuat tekan yang 


\section{DynamicSainT}

Jilid. V No. 1., April 2020

dhasilkan lebih tinggi daripada dengan perawatan suhu udara terbuka.

\subsection{Hasil pengujian kuat tekan}

Pengujian kuat tekan dilakukan pada usia 3,7,14 dan 28 hari Pengujian kuat tekan dilakukan menggunakan Universal Testing Machine dengan kapasitas $100 \mathrm{Kn}$ dengan rumus yang dipergunakan adalah sebagai berikut:

$$
f^{\prime} c=F / A
$$

dimana

$\mathrm{f}^{\prime} \mathrm{c}=$ Kuat Tekan $(\mathrm{MPa})$

$\mathrm{F}=$ Beban Tekan $(\mathrm{N})$

A $=$ Luas Penampang $\left(\mathrm{mm}^{2}\right)$

\section{Kuat Tekan Mortar 15 m curing air}

Tabel 4. Kuat tekan mortar geopolimer 15 molar perawatan perendaman air

\begin{tabular}{|c|c|c|c|c|c|c|c|}
\hline $\begin{array}{c}\text { Nama } \\
\text { benda } \\
\text { uji }\end{array}$ & \multirow{2}{*}{$\begin{array}{c}\text { Berat } \\
(\mathrm{gr})\end{array}$} & \multirow{2}{*}{$\begin{array}{c}\text { Luas } \\
(\mathrm{mm})\end{array}$} & $\begin{array}{c}\text { pembuata } \\
\mathrm{n}\end{array}$ & $\begin{array}{c}\text { pengujia } \\
\mathrm{n}\end{array}$ & $\begin{array}{c}\text { Beban } \\
\text { (N/m } \\
\mathrm{m})\end{array}$ & $\begin{array}{c}\text { F'c } \\
\text { (MP } \\
\text { a) }\end{array}$ & $\begin{array}{c}\text { Rata } \\
\text {-rata }\end{array}$ \\
\hline CA 31 & 193 & 2500 & $30 / 06 / 19$ & $3 / 07 / 19$ & 3600 & 1,44 & \\
CA 32 & 214 & 2500 & $30 / 06 / 19$ & $3 / 07 / 19$ & 4700 & 1,88 & 1,64 \\
CA 33 & 203 & 2500 & $30 / 06 / 19$ & $3 / 07 / 19$ & 4000 & 1,6 & \\
\hline CA 71 & 189 & 2500 & $30 / 06 / 19$ & $7 / 07 / 19$ & 6000 & 2,4 & \\
CA 72 & 189 & 2500 & $30 / 06 / 19$ & $7 / 07 / 19$ & 7300 & 2,92 & 2.76 \\
CA 73 & 191 & 2500 & $30 / 06 / 19$ & $7 / 07 / 19$ & 7400 & 2,96 & \\
\hline CA 141 & 193 & 2500 & $23 / 06 / 19$ & $7 / 07 / 19$ & 7800 & 3,12 & \\
CA 142 & 214 & 2500 & $23 / 06 / 19$ & $7 / 07 / 19$ & 8100 & 3,24 & 3.16 \\
CA 143 & 203 & 2500 & $23 / 06 / 19$ & $7 / 07 / 19$ & 7800 & 3,12 & \\
\hline CA 281 & 221 & 2500 & $12 / 06 / 19$ & $10 / 07 / 19$ & 8600 & 3,44 & \\
CA 282 & 218 & 2500 & $12 / 06 / 19$ & $10 / 07 / 19$ & 8900 & 3,56 & 3.49 \\
CA 283 & 215 & 2500 & $12 / 06 / 19$ & $10 / 07 / 19$ & 8700 & 3,48 & \\
\hline
\end{tabular}

\section{Mortar usia 3 hari}

- Luas kubus $(\mathrm{A}) \quad=2500 \mathrm{~mm}$

Pmax $\quad$ CA $31=3600 \mathrm{~N}$

Kuat tekan $\left(\mathrm{f}^{\prime} \mathrm{c}\right)=\frac{\mathrm{P}}{\mathrm{A}}=\frac{3600}{2500}$

(f'c)

$$
=1,44 \mathrm{MPa}
$$

- $\quad$ Luas kubus $(\mathrm{A}) \quad=2500 \mathrm{~mm}$

Pmax $\quad$ CA $32=4700 \mathrm{~N}$

Kuat tekan $\left(\mathrm{f}^{\prime} \mathrm{c}\right) \quad=\frac{\mathrm{P}}{\mathrm{A}}=\frac{4700}{2500}$

$\left(f^{\prime} c\right)=1,88 \mathrm{MPa}$

- $\quad$ Luas kubus $(\mathrm{A}) \quad=2500 \mathrm{~mm}$

Pmax $\quad$ CA 33 $=4000 \mathrm{~N}$

Kuat tekan $\left(\mathrm{f}^{\prime} \mathrm{c}\right) \quad=\frac{\mathrm{P}}{\mathrm{A}}=\frac{4000}{2500}$

(f'c) $\quad=1,6 \mathrm{MPa}$

\section{Mortar usia 7 hari}

- Luas kubus (A) = $2500 \mathrm{~mm}$
Pmax $\quad$ CA $71=6000 \mathrm{~N}$

Kuat tekan $\left(\mathrm{f}^{\prime} \mathrm{c}\right) \quad=\frac{\mathrm{P}}{\mathrm{A}}=\frac{6000}{2500}$

(f'c) $\quad=2,4 \mathrm{MPa}$

- $\quad$ Luas kubus $(\mathrm{A}) \quad=2500 \mathrm{~mm}$

Pmax $\quad$ CA $72=7300 \mathrm{~N}$

Kuat tekan $\left(\mathrm{f}^{\prime} \mathrm{c}\right) \quad=\frac{\mathrm{P}}{\mathrm{A}}=\frac{7300}{2500}$

(f'c)

$$
=2,92 \mathrm{MPa}
$$

- $\quad$ Luas kubus $(\mathrm{A}) \quad=2500 \mathrm{~mm}$

Pmax $\quad$ CA $73=7400 \mathrm{~N}$

Kuat tekan $\left(\mathrm{f}^{\prime} \mathrm{c}\right) \quad=\frac{\mathrm{P}}{\mathrm{A}}=\frac{7400}{2500}$

$\left(\mathrm{f}^{\prime} \mathrm{c}\right) \quad=2,96 \mathrm{MPa}$

Mortar usia 14 hari

- Luas kubus $(\mathrm{A}) \quad=2500 \mathrm{~mm}$

Pmax CA $141=7800 \mathrm{~N}$

Kuat tekan $\left(\mathrm{f}^{\prime} \mathrm{c}\right) \quad=\frac{\mathrm{P}}{\mathrm{A}}=\frac{7800}{2500}$

(f'c)

$=3,12 \mathrm{MPa}$

Luas kubus $(\mathrm{A}) \quad=2500 \mathrm{~mm}$

Pmax CA $142=8100 \mathrm{~N}$

Kuat tekan $\left(f^{\prime} c\right) \quad=\frac{P}{A}=\frac{8100}{2500}$

(f'c) $\quad=3,24 \mathrm{MPa}$.

Luas kubus $(\mathrm{A}) \quad=2500 \mathrm{~mm}$

PmaxCA $142=7800 \mathrm{~N}$

Kuat tekan $\left(\mathrm{f}^{\prime} \mathrm{c}\right) \quad=\frac{\mathrm{P}}{\mathrm{A}}=\frac{7800}{2500}$

(f'c)

$=3,12 \mathrm{MPa}$

\section{Mortar usia 28 hari}

- $\quad$ Luas kubus (A) $\quad=2500 \mathrm{~mm}$

Pmax CA $281=8700 \mathrm{~N}$

Kuat tekan $\left(\mathrm{f}^{\prime} \mathrm{c}\right) \quad=\frac{\mathrm{P}}{\mathrm{A}}=\frac{8700}{2500}$

(f'c)

$=3,44 \mathrm{MPa}$

- $\quad$ Luas kubus $(\mathrm{A}) \quad=2500 \mathrm{~mm}$

Pmax CA $282=8900 \mathrm{~N}$

Kuat tekan $\left(\mathrm{f}^{\prime} \mathrm{c}\right) \quad=\frac{\mathrm{P}}{\mathrm{A}}=\frac{8900}{2500}$

$\left(f^{\prime} c\right) \quad=3,56 \mathrm{MPa}$

- $\quad$ Luas kubus $(\mathrm{A}) \quad=2500 \mathrm{~mm}$

Pmax CA $282=8700 \mathrm{~N}$

Kuat tekan $\left(\mathrm{f}^{\prime} \mathrm{c}\right) \quad=\frac{\mathrm{P}}{\mathrm{A}}=\frac{8700}{2500}$

(f'c)

$=3,48 \mathrm{MPa}$ 


\section{DynamicSainT}

Jilid. V No. 1., April 2020

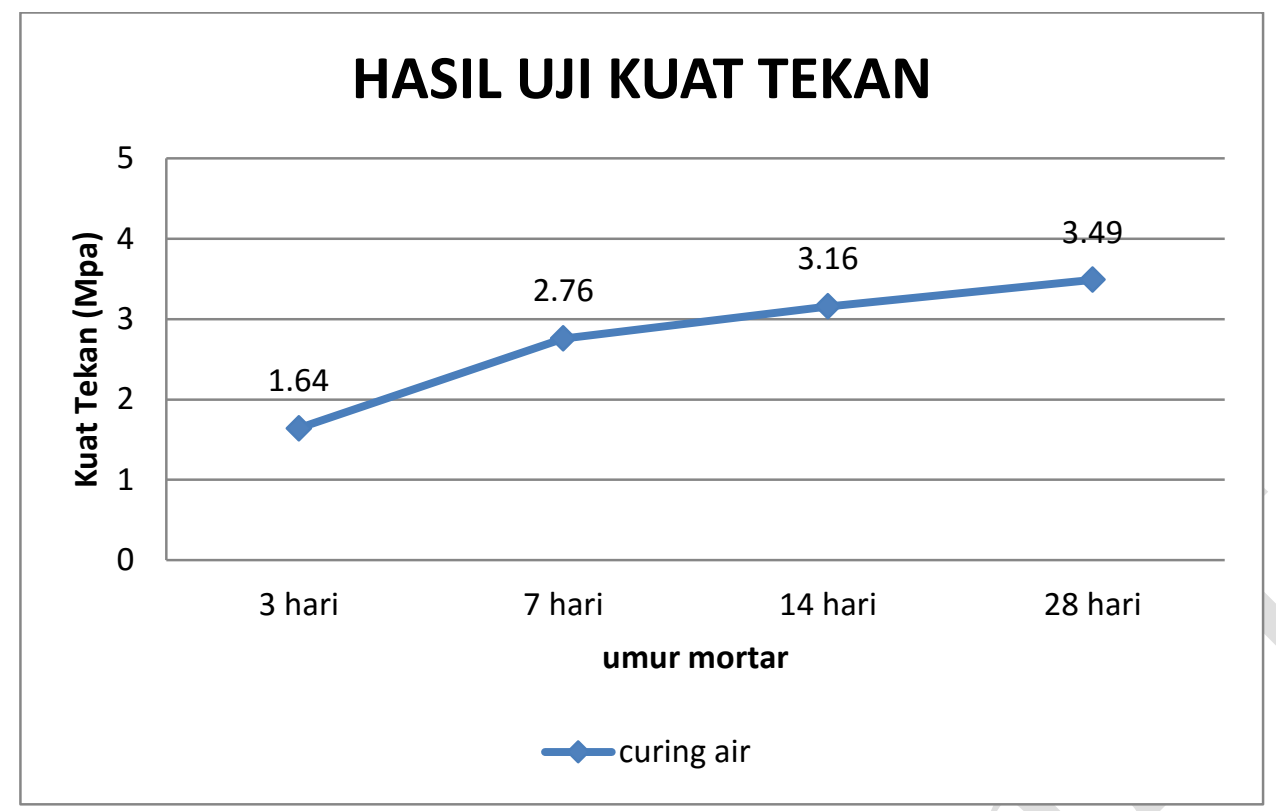

Grafik 1. Kuat tekan mortar geopolimer perawatan perendaman air

Dari grafik 1 diketahui bahwa kuat tekan benda uji terendah berada pada usia 3 hari yaitu sebesar 1,64 mpa, pada usia 7 hari kuat tekan sebesar 2,76 mpa ,pada usia 14 hari sebesar 3,16 mpa dan terus mengalami peningkatan hingga pada usia 28 hari mencapai 3,49 mpa.

\section{Kuat Tekan Mortar geopolimer 15 molar curing udara}

Tabel 5. Kuat tekan mortar geopolimer 15 molar perawatan kondisi kering

\begin{tabular}{|c|c|c|c|c|c|c|c|}
\hline \multirow{2}{*}{$\begin{array}{c}\text { Nama } \\
\text { benda } \\
\text { uji }\end{array}$} & \multirow[b]{2}{*}{$\begin{array}{c}\text { Berat } \\
\text { (gram) }\end{array}$} & \multirow[b]{2}{*}{$\begin{array}{l}\text { Luas } \\
(\mathrm{mm})\end{array}$} & \multicolumn{2}{|c|}{ Tanggal } & \multirow{2}{*}{$\begin{array}{c}\text { Beban } \\
(\mathrm{N} / \mathrm{m} \\
\mathrm{m})\end{array}$} & \multirow{2}{*}{$\begin{array}{l}\text { F'c } \\
\text { (M } \\
\text { Pa) }\end{array}$} & \multirow[b]{2}{*}{$\begin{array}{l}\text { Rata } \\
\text {-rata }\end{array}$} \\
\hline & & & $\begin{array}{c}\text { pembu } \\
\text { atan }\end{array}$ & $\begin{array}{c}\text { penguj } \\
\text { ian }\end{array}$ & & & \\
\hline $\mathrm{Cu} 31$ & 219 & 2500 & 4/07/19 & $4 / 07 / 19$ & 2600 & 1,04 & \multirow{3}{*}{1,04} \\
\hline $\mathrm{Cu} 32$ & 219 & 2500 & $1 / 07 / 19$ & $4 / 07 / 19$ & 2700 & 1,08 & \\
\hline $\mathrm{Cu} 33$ & 213 & 2500 & $1 / 07 / 19$ & $4 / 07 / 19$ & 2900 & 1,16 & \\
\hline $\mathrm{Cu} 71$ & 206 & 2500 & $1 / 07 / 19$ & $8 / 07 / 19$ & 6300 & 2,52 & \multirow{3}{*}{2,32} \\
\hline $\mathrm{Cu} 72$ & 212 & 2500 & $\begin{array}{l}1007 / 19 \\
1 / 0\end{array}$ & & 5600 & 2,24 & \\
\hline $\mathrm{Cu} 73$ & 211 & 2500 & $1 / 07 / 19$ & $8 / 07 / 19$ & 5500 & 2,2 & \\
\hline & & & $23 / 06 / 1$ & & & & \multirow{4}{*}{3,03} \\
\hline $\begin{array}{l}\text { CU141 } \\
\text { CU142 }\end{array}$ & $\begin{array}{l}217 \\
234\end{array}$ & $\begin{array}{l}2500 \\
2500\end{array}$ & $23 / 06 / 1$ & $\begin{array}{l}7 / 07 / 19 \\
7 / 07 / 19\end{array}$ & $\begin{array}{l}8600 \\
7500\end{array}$ & $\begin{array}{c}3,44 \\
3\end{array}$ & \\
\hline CU143 & 223 & 2500 & $\begin{array}{c}9 \\
23 / 061\end{array}$ & $7 / 07 / 19$ & 6600 & 2,64 & \\
\hline & & & $\begin{array}{c}20 / 0 / 1 \\
9\end{array}$ & & & & \\
\hline & & & $\begin{array}{c}12 / 06 / 1 \\
9\end{array}$ & $\begin{array}{c}10 / 07 / 1 \\
9\end{array}$ & & & \multirow{4}{*}{3,13} \\
\hline CU 281 & 222 & $\begin{array}{l}2500 \\
2500\end{array}$ & $12 / 06 / 1$ & $10 / 07 / 1$ & 7900 & 3,16 & \\
\hline & $\begin{array}{r}218 \\
210\end{array}$ & $\begin{array}{l}2500 \\
2500\end{array}$ & & & & & \\
\hline CU 283 & 210 & 2500 & $12 / 06 / 1$ & $10 / 07 / 1$ & 8000 & 3,2 & \\
\hline
\end{tabular}

\section{Mortar usia 3 hari}

- $\quad$ Luas kubus $(\mathrm{A}) \quad=2500 \mathrm{~mm}$

Pmax CU 31 $=2600 \mathrm{~N}$

Kuat tekan $\left(\mathrm{f}^{\prime} \mathrm{c}\right) \quad=\frac{\mathrm{P}}{\mathrm{A}}=\frac{2600}{2500}$

(f'c) $=1,04 \mathrm{MPa}$
- $\operatorname{Luas}$ kubus $(\mathrm{A}) \quad=2500 \mathrm{~mm}$ Pmax CU $32=2700 \mathrm{~N}$

Kuat tekan $\left(\mathrm{f}^{\prime} \mathrm{c}\right) \quad=\frac{\mathrm{P}}{\mathrm{A}}=\frac{2700}{2500}$ (f'c) $=1,08 \mathrm{MPa}$

Luas kubus $(\mathrm{A}) \quad=2500 \mathrm{~mm}$ Pmax CU 33 $=2900 \mathrm{~N}$

Kuat tekan $\left(\mathrm{f}^{\prime} \mathrm{c}\right) \quad=\frac{\mathrm{P}}{\mathrm{A}}=\frac{2900}{2500}$ (f'c) $=1,16 \mathrm{MPa}$

\section{Mortar usia 7 hari}

- $\operatorname{Luas}$ kubus (A) $=2500 \mathrm{~mm}$ Pmax CU71 $=6300 \mathrm{~N}$

Kuat tekan $\left(\mathrm{f}^{\prime} \mathrm{c}\right) \quad=\frac{\mathrm{P}}{\mathrm{A}}=\frac{6300}{2500}$ (f'c) $=2,52 \mathrm{MPa}$

- $\operatorname{Luas}$ kubus (A) $=2500 \mathrm{~mm}$ Pmax CU $72=5600 \mathrm{~N}$ Kuat tekan (f'c) $=\frac{\mathrm{P}}{\mathrm{A}}=\frac{5600}{2500}$, (f'c) $=2,24 \mathrm{MPa}$

- $\operatorname{Luas}$ kubus (A) $\quad=2500 \mathrm{~mm}$ Pmax CU 73 $=5500 \mathrm{~N}$

Kuat tekan $\left(\mathrm{f}^{\prime} \mathrm{c}\right) \quad=\frac{\mathrm{P}}{\mathrm{A}}=\frac{5500}{2500}$ (f'c)$$
=2,2 \mathrm{MPa}
$$

\section{Mortar usia 14 hari}

- $\operatorname{Luas}$ kubus (A) $=2500 \mathrm{~mm}$
Pmax
CU 141
$=8600 \mathrm{~N}$
Kuat tekan $\left(\mathrm{f}^{\prime} \mathrm{c}\right) \quad=\frac{\mathrm{P}}{\mathrm{A}}=\frac{8600}{2500}$ 


\section{DynamicSainT}

Jilid. V No. 1., April 2020

(f'c)

$=3,44 \mathrm{MPa}$

- $\operatorname{Luas}$ kubus $(\mathrm{A}) \quad=2500 \mathrm{~mm}$

Pmax CU 142 $=7500 \mathrm{~N}$

Kuat tekan $\left(\mathrm{f}^{\prime} \mathrm{c}\right) \quad=\frac{\mathrm{P}}{\mathrm{A}}=\frac{7500}{2500}$

(f'c) $=3 \mathrm{MPa}$

- $\operatorname{Luas}$ kubus $(\mathrm{A}) \quad=2500 \mathrm{~mm}$

Pmax CU $142=6600 \mathrm{~N}$

Kuat tekan $\left(\mathrm{f}^{\prime} \mathrm{c}\right) \quad=\frac{\mathrm{P}}{\mathrm{A}}=\frac{6600}{2500}$

(f'c) $=2,64 \mathrm{MPa}$

\section{Mortar usia 28 hari}

- $\operatorname{Luas}$ kubus (A) $=2500 \mathrm{~mm}$

Pmax CU 281 $=8700 \mathrm{~N}$

Kuat tekan (f'c) $=\frac{\mathrm{P}}{\mathrm{A}}=\frac{7900}{2500}$

(f'c)

$=3,16 \mathrm{MPa}$

- $\operatorname{Luas}$ kubus $(\mathrm{A}) \quad=2500 \mathrm{~mm}$

Pmax CU $282=7600 \mathrm{~N}$

Kuat tekan $\left(\mathrm{f}^{\prime} \mathrm{c}\right) \quad=\frac{\mathrm{P}}{\mathrm{A}}=\frac{7600}{2500}$

(f'c)

$=3,04 \mathrm{MPa}$

- $\operatorname{Luas}$ kubus (A) $=2500 \mathrm{~mm}$

Pmax CU 282 $=8000 \mathrm{~N}$

Kuat tekan $\left(\mathrm{f}^{\prime} \mathrm{c}\right) \quad=\mathrm{P} / \mathrm{A}=\frac{8000}{2500}$

(f'c)

$=3,2 \mathrm{MPa}$

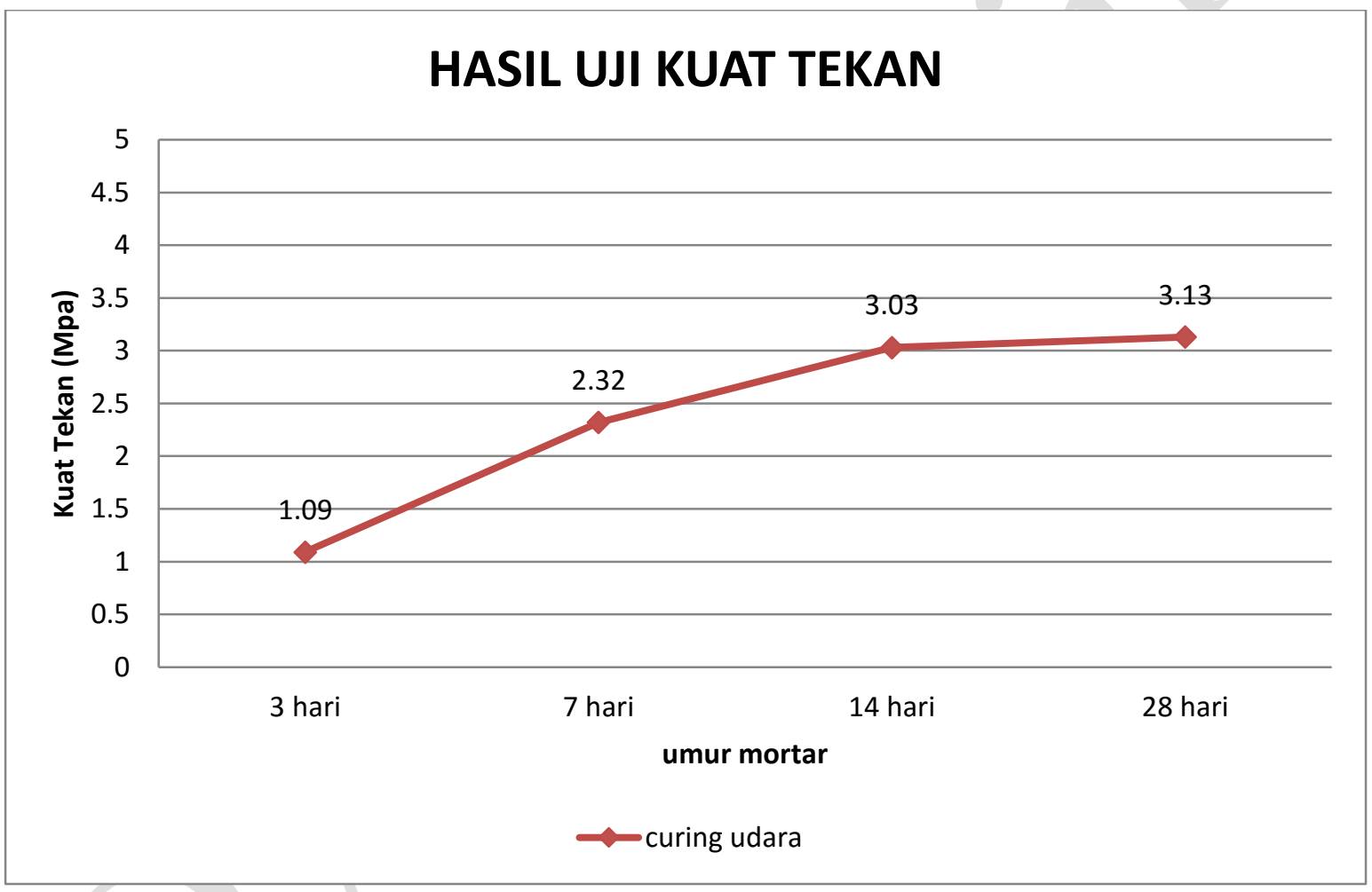

Grafik 2. Kuat tekan mortar geopolimer 15 molar perawatan kondisi kering 


\section{DynamicSainT}

Jilid. V No. 1., April 2020

Pada grafik 2 diketahui bahwa kuat tekan benda uji terendah berada pada usia 3 hari yaitu sebesar 1,09 mpa, pada usia 7 hari kuat tekan sebesar 2,32 mpa, pada usia 14 hari sebesar 3,03 mpa dan terus mengalami peningkatan hingga pada usia 28 hari mencapai 3,13 mpa

\section{KESIMPULAN DAN SARAN}

\subsection{Kesimpulan}

a) Hasil Penelitian dengan menggunakan abu sekam padi dan limbah abu hasil pembakaran batubara dari AMP diperoleh mortar geopolymer dengan komposisi :
Abu Terbang (85\%)
: 425 gram
Abu sekam (15\%)
: 75 gram
$\mathrm{NaOH}(15$ molar $): 165$ gram
Air
: $275 \mathrm{ml}$

Semakin banyak persentase abu terbang yang digunakan dalam komposisi campuran maka mutu mortar geopolimer lebih baik.

b) Metode perawatan yang paling baik dilakukan untuk mortar geopolimer adalah perendaman air menunjukkan hasil yang lebih tinggi dibandingkan dengan uji kuat tekan mortar metode perawatan suhu ruangan

c) Hasil kuat tekan terbaik mortar ialah pada usia 28 hari dengan kuat tekan 3,13 MPa untuk curing udara dan 3,49 $\mathrm{MPa}$ untuk curing perendaman dalam air.

\subsection{Saran}

Setelah melalui proses penelitian, penulis memberikan beberapa saran jika ke depannya ada yang akan melanjutkan penelitian ini.

1. Perlu dilakukan penelitian lebih lanjut dan lebih spesifik mengenai komposisi campuran geopolimer yang optimum sehingga dapat manghasilkan mutu mortar yang lebih baik lagi.

2. Sebaiknya mempersiapkan alat bahan penelitian jauh hari sebelum pelaksanakan proses penelitian.
3. Menambah variasi material selain abu terbang yang akan digunakan dalam penelitian selanjutnya.

4. Menambahkan alternatif aktifator lain dalam penelitian.

\section{DAFTAR PUSTAKA}

1. Bienias, J., Walczak, M., Surowska, B., \& Sobczak, J. (2003). Microstructure and Corrosion Behavior of Aluminium Fly

Ash Composite. Journal of Ontoelectronics and Advanced Materials, 493-502.

2. Davidovits, J. (1991). Geopolymers: inorganic polymeric new materials. Journal of Thermal Analysis and calorimetry, 1633-1656.

3. Husin, A. A. (2005). Pemanfaatan limbah untuk Bahan Bangunan. Jakarta.

4. Ilmiah, N. (2017). Pengaruh Penambahan Abu Sekam Padi sebagai Pozzolan pada Binder Geopolimer Menggunakan Alkali Aktivator Sodium Silikat (Na2SiO3) serta Sodium Hidroksida (NaOH). Surabaya: Institut Teknologi Sepuluh Nopember.

5. Kasyanto, H. (2012). Tinjauan Kuat Tekan Geopolimer Berbahan Dasar Fly Ash dengan Aktivator Sodium Hidroksida dan Sodium Silikat. Industrial Research Workshop and National Seminar 2012 (pp. 1-6). Bandung: Politeknik Negeri Bandung.

6. Musbar, F. R., \& Mahyar, H. (2010). Pemanfaatan Abu Sekam Padi Sebagai Bahan Campuran Beton Agropolymer. Jurnal Teknik Sipil, Politeknik Negeri Lhokseumawe, 33-52.

7. Nugraha, P., \& Antoni. (2007). Teknologi Beton dari Material, Pembuatan, ke Beton Kinerja Tinggi. Yogyakarta: Andi Offset.

8. Rangan, P. R., Irmawaty, R., Amiruddin, A., \& Bakri, B. (2020). CHARACTERISTICS OF GEOPOLYMER USING RICE STRAW ASH, FLY ASH AND LATERITE SOIL AS ECO- 


\section{DynamicSainT}

Jilid. V No. 1., April 2020

FRIENDLY MATERIALS.

International Journal of GEOMATE,

77-81.

https://www.geomatejournal.com/sites

/default/files/articles/77-81-13457-

Parea-Sept-2020-73.pdf

9. Rangan, P. R., Irmawaty, R., Amiruddin, A., \& Bakri, B. (2020). Strength performance of sodium hydroxide-activated fly ash, rice straw ash, and laterite soil geopolymer mortar. IOP Conf. Series: Earth and Environmental Science 473 (2020) O12123 IOP Publishing (pp. 1-10). Makassar.

https://iopscience.iop.org/article/10.10 $\underline{88 / 1755-1315 / 473 / 1 / 012123 / p d f}$

10. Sturm, P., G.JG, G., Brouwers, H., \& Kuhne, H. (2016). Synthesizing onepart geopolymers from rice husk ash. Construction and Building Materials.

11. Sutikno. (2003). Panduan Praktek Beton. Surabaya: Universitas Negeri Surabaya.

12. Tjokrodimulyo, K. (2007). Teknologi Beton. Yogyakarta: Biro Penerbit Teknik Sipil, Universitas Gadjah Mada.

13. Retno. (2006) http://digilib.unila.ac.id/11377/4/BAB \%202.pdf

14. ASTM C 618 - 91 , Unsur senyawa kimia dan sifat fisika pada fly ash

15. Bandar Standardisasi Nasional, SII 0031-81, 1981 tentang Jenis-Jenis Semen

16. SNI S-15-1990-F tentang spesifikasi abu terbang sebagai bahan tambahan untuk campuran beton 